\title{
Bioaccumulation of Trace Elements in Ruditapes philippinarum from China: Public Health Risk Assessment Implications
}

\author{
Feng Yang ${ }^{\dagger}$, Liqiang Zhao ${ }^{\dagger}$, Xiwu Yan * and Yuan Wang \\ College of Fisheries and Life Science, Dalian Ocean University, Dalian 116023, China; \\ E-Mails: yangfeng@dlou.edu.cn (F.Y.); zhaoliqiang@dlou.edu.cn (L.Z.); \\ wangyuan@dlou.edu.cn (W.Y.)
}

$\dagger$ These authors contributed equally to this work.

* Author to whom correspondence should be addressed; E-Mail: yanxiwu@ dlou.edu.cn; Tel./Fax: +86-0411-8476-3026.

Received: 25 January 2013; in revised form: 26 March 2013 / Accepted: 27 March 2013 / Published: 2 April 2013

\begin{abstract}
The Manila clam Ruditapes philippinarum is one of the most important commercial bivalve species consumed in China. Evaluated metal burden in bivalve molluscs can pose potential risks to public health as a result of their frequent consumption. In this study, concentrations of 10 trace elements ( $\mathrm{Cu}, \mathrm{Zn}, \mathrm{Mn}, \mathrm{Se}, \mathrm{Ni}, \mathrm{Cd}, \mathrm{Cr}, \mathrm{Pb}, \mathrm{Hg}$ and $\mathrm{As}$ ) were determined in samples of the bivalve Ruditapes philippinarum, collected from nine mariculture zones along the coast of China between November and December in 2010, in order to evaluate the status of elemental metal pollution in these areas. Also, a public health risk assessment was untaken to assess the potential risks associated with the consumption of clams. The ranges of concentrations found for $\mathrm{Cu}, \mathrm{Zn}, \mathrm{Mn}, \mathrm{Se}, \mathrm{Ni}, \mathrm{Cd}, \mathrm{Cr}$, $\mathrm{Pb}, \mathrm{Hg}$ and $\mathrm{As}$ in $R$. philippinarum were 12.1-38.0, 49.5-168.3, 42.0-68.0, 4.19-8.71, $4.76-14.32,0.41-1.11,0.94-4.74,0.32-2.59,0.03-0.23$ and $0.46-11.95 \mathrm{mg} \cdot \mathrm{kg}^{-1}$ dry weight, respectively. Clear spatial variations were found for $\mathrm{Cu}, \mathrm{Zn}, \mathrm{Cr}, \mathrm{Pb}, \mathrm{Hg}$ and $\mathrm{As}$, whereas $\mathrm{Mn}, \mathrm{Se}, \mathrm{Ni}$, and $\mathrm{Cd}$ did not show significant spatial variation. Hotspots of trace element contamination in $R$. philippinarum can be found along the coast of China, from the north to the south, especially in the Bohai and Yellow Seas. Based on a $58.1 \mathrm{~kg}$ individual consuming $29 \mathrm{~g}$ of bivalve molluscs per day, the values of the estimated daily intake (EDI) of trace elements analyzed were significantly lower than the values of the accepted daily intake (ADI) established by Joint Food and Agriculture Organization/World Health
\end{abstract}


Organization Expert Committee on Food Additives (JFAO/WHO) and the guidelines of the reference does (RfD) established by the United States Environmental Protection Agency (USEPA). Additionally, the risk of trace elements to humans through $R$. philippinarum consumption was also assessed. The calculated hazard quotients (HQ) of all trace elements were less than 1. Consequently, there was no obvious public risk from the intake of these trace elements through $R$. philippinarum consumption.

Keywords: Ruditapes philippinarum; trace element; public health; risk assessment; China

\section{Introduction}

The rapid development of industry and agriculture has been coupled with increasing environmental pollution, especially in developing countries [1]. As a consequence of these enhanced anthropogenic activities, a large amount of harmful pollutants such as persistent organic pollutants and heavy metals have been discharged into the estuarine and coastal waters over the past decades, which have placed increasing pressures on the corresponding estuarine and coastal ecosystems [2]. The input of these toxic wastes into the estuarine and coastal waters can result in deleterious effects on wildlife habitats, degradation of aquatic ecosystems and potential human health risks [3-6].

Among these harmful pollutants, much attention has been focused on heavy metal pollution in the estuarine and coastal waters [7-9]. Heavy metals, generally classified as non-biodegradable pollutants, can be strongly accumulated in surface sediments and aquatic organisms, and subsequently be transferred to humans through the food chain $[10,11]$. As is well-known, heavy metals, even at trace levels, can lead to adverse human health effects, including neurological diseases and cancers $[12,13]$. Consequently, researchers have classified heavy metals in the highest risk category for human health. A recent review reported that industrial and domestic sewage discharges, mining, smelting and $e$-wastes recycling are the main sources contributing to metal pollution in estuarine and coastal waters in China [6]. In recent years, very high metal concentrations in seawater, surface sediments and aquatic organisms collected from heavily industrialized areas have been intensively reported in China [14-16]. Consequently, the public health problems associated with consumption of contaminated seafood are of great interest today. Elevated heavy metal contamination in estuarine and coastal waters has increased the risk of heavy metal exposure to humans through consumption of contaminated seafood.

The Manila clam Ruditapes philippinarum is one of the most important commercial bivalve species consumed in China, and is an important seafood for humans due to its high nutritional value and delicate flavor. It is widely distributed in estuarine and coastal waters and has been cultivated for more than 50 years in China. Clam farming, particularly along the northern coast of China, has become an important component of the marine fishery industry [17]. The production of this species has reached levels of over 3.0 million tons per annum in China, which accounts for approximately $70 \%$ of mudflat fishery production and $90 \%$ of total World production [18]. Furthermore, they are also widely used as sentinel species for monitoring the quality of estuarine and coastal waters. As filter-feeding bivalves, they are well known to accumulate heavy metals from seawater, sediments and ingested food materials to concentrations greatly in excess of that found in their adjacent environments [19-21]. Additionally, 
they also conform to some desirable criteria such as widespread distribution, a sedentary lifestyle and ease of collection, making them the prime candidate for studying the heavy metal contamination in estuarine and coastal waters [22].

This study represents a preliminary investigation of levels of ten trace elements $(\mathrm{Cu}, \mathrm{Zn}, \mathrm{Mn}, \mathrm{Se}$, $\mathrm{Ni}, \mathrm{Cd}, \mathrm{Cr}, \mathrm{Pb}, \mathrm{Hg}$ and $\mathrm{As}$ ) in Manila clam samples collected along the coast of China. The primary purpose of our study was to examine whether this bivalve species was contaminated with these selected trace elements. Potential human health risk assessment was then conducted to evaluate whether it presented any potential hazard to humans as a result of consumption. From a public health point of view, our study will provide consumers with better knowledge of public health in connection with seafood consumption.

\section{Methods}

\subsection{Sampling}

Manila clams were collected from nine sampling sites along the coast of China between November and December in 2010 (Figure 1).

Figure 1. Map of the sampling sites along the coast of China.

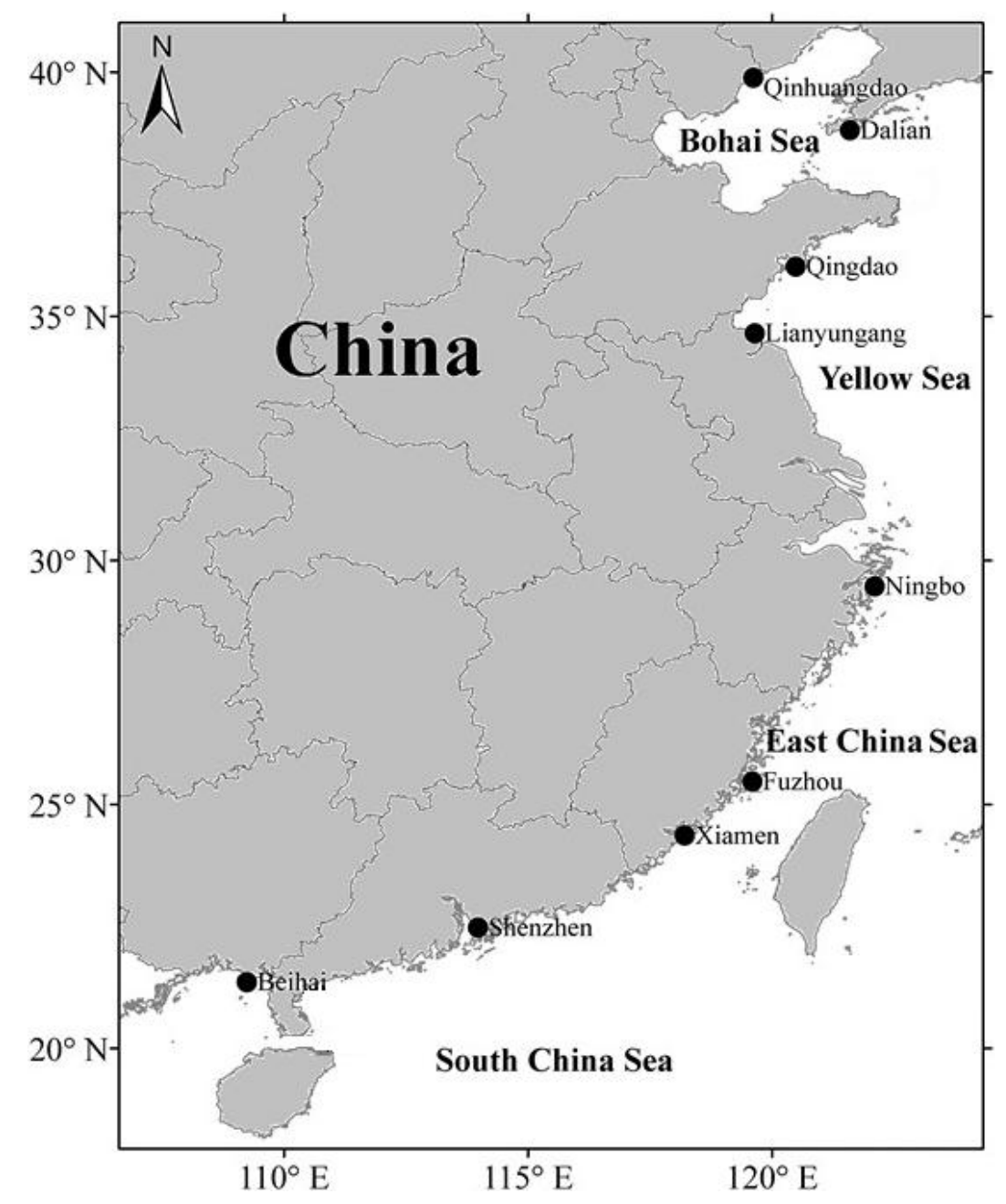


These collected samples were transferred to the Biological Laboratory of Dalian Ocean University and cultured in filtered seawater for $24 \mathrm{~h}$ depuration. 10 individuals from each site, with similar size, weight and shape, were pooled to prepare a composite specimen in order to minimize individual variations in trace elements determined. Differences in the shell length and wet weight of samples among all sampling sites were not statically significant. Three replicates were performed at each sampling site. The whole soft tissues of clams were dissected with a plastic knife, rinsed five times with deionized water (resistivity, $18.2 \mathrm{M} \Omega / \mathrm{cm}$; Millipore, Co., Bedford, MA, USA), freeze-dried, homogenized and then stored in polyethylene bags at $-20^{\circ} \mathrm{C}$ until future analysis.

\subsection{Trace Element Analysis}

Approximated $0.5 \mathrm{~g}$ of dry sample was digested with $6 \mathrm{~mL}$ of $\mathrm{HNO}_{3}(65 \%)$ and $2 \mathrm{~mL}$ of $\mathrm{H}_{2} \mathrm{O}_{2}$ (30\%) in a microwave digestion system (MARSX, CEM, Mathews, NC, USA) for $30 \mathrm{~min}$. After cooling, the resultant solution was diluted to $50 \mathrm{~mL}$ with deionized water. Concentrations of $\mathrm{Cu}$, $\mathrm{Zn}, \mathrm{Mn}, \mathrm{Se}, \mathrm{Ni}, \mathrm{Cd}, \mathrm{Cr}$ and $\mathrm{Pb}$ were determined by inductively coupled plasma atomic emission spectrometer (ICP-AES, IRIS intrepid 11XSP, Thermo Electron Co., San Jose, CA, USA), while Hg and As were determined by atomic fluorescence spectrometer (AFS9130, Beijing Titan Instruments Co. Ltd., Beijing, China). Standard reference materials (mussel tissue sample, GBW08571, from the National Research Center for Certified Reference Materials, Beijing, China) were used for quality assurance and quality control procedures. The results showed good agreement between the certified and the analytical values. All trace elements concentrations were given on a dry weight basis $\left(\mathrm{mg} \cdot \mathrm{kg}^{-1}\right.$ dry weight).

\subsection{Human Exposure Assessment}

The potential human health risk assessment was conducted by considering the following parameters according to Onsanit et al. [23]. The estimated daily intake (EDI), provisional tolerance weekly intake (PTWI), accepted daily intake (ADI), and reference dose (RfD) were previously established by the Joint FAO/WHO Expert Committee on Food Additives (JECFA) [24], and the United States Environmental Protection Agency [25]. The EDI (mg/kg bw/day) was calculated using the following equation:

$$
\mathrm{EDI}=C_{\text {bivalve }} \times\left[\frac{d c_{\text {bivalve }}}{b w}\right]
$$

where $C_{\text {bivalve }}=$ average trace metal concentrations in $R$. philippinarum $\left(\mathrm{mg} \cdot \mathrm{kg}^{-1}\right.$ wet weight), $d c_{\text {bivalve }}=$ daily bivalve consumption $\left(\mathrm{g} \cdot \mathrm{day}^{-1}\right)$ per capita for the Chinese population as recorded by the FAO [26], and $b_{W}=$ average body weight ( $\mathrm{kg}$ ) of the target population [27].

The hazard quotient (HQ) was calculated by dividing the EDI by the established RfD to assess human risk associated with bivalve consumption. There would be no obvious hazard if the value of HQ was less than 1 . The HQ was calculated using the following equation:

$$
\mathrm{HQ}=\frac{E D I}{R f D}
$$




\section{Results}

\subsection{Geographical Distribution of Trace Elements in Clams}

Trace element concentrations in clams collected from sampling sites along the coast of China are shown in Figure 2. In general, concentrations of selected trace elements in clams were consistent and ranked, in decreasing order of concentration, as follows: $\mathrm{Zn}>\mathrm{Mn}>\mathrm{Cu}>\mathrm{Ni}>\mathrm{Se}>\mathrm{As}>\mathrm{Cr}>\mathrm{Cd}>\mathrm{Pb}>\mathrm{Hg}$. Differences in trace element concentrations from different sampling sites are described below.

$\mathrm{Zn}, \mathrm{Mn}, \mathrm{Cu}$, and Se are well-known essential trace elements for all living organisms. As shown in Figure 2, $\mathrm{Zn}$ was the most prominent element detected in $R$. philippinarum, with the lowest level, of $49.5 \mathrm{mg} \cdot \mathrm{kg}^{-1}$, being found in Ningbo and the highest level, of $168.3 \mathrm{mg} \cdot \mathrm{kg}^{-1}$, occurring in Qinghuangdao. The minimum and maximum Mn levels were found to be $45.0 \mathrm{mg} \cdot \mathrm{kg}^{-1}$ in Xiamen, and $68.0 \mathrm{mg} \cdot \mathrm{kg}^{-1}$ in Dalian, respectively, while the lowest and highest $\mathrm{Cu}$ levels were $12.1 \mathrm{mg} \cdot \mathrm{kg}^{-1}$ in Beihai, and $38.0 \mathrm{mg} \cdot \mathrm{kg}^{-1}$ in Qinghuangdao, respectively. The lowest and highest levels of Se were, respectively, $4.19 \mathrm{mg} \cdot \mathrm{kg}^{-1}$ in Dalian, and $8.71 \mathrm{mg} \cdot \mathrm{kg}^{-1}$ in Shenzheng. Ni and $\mathrm{Cr}$ have been identified as potential essential metals. The lowest and highest levels of $\mathrm{Ni}$ were $4.76 \mathrm{mg} \cdot \mathrm{kg}^{-1}$ in Fuzhou, and $14.32 \mathrm{mg} \cdot \mathrm{kg}^{-1}$ in Qingdao, respectively, while the minimum and maximum Cr levels were found to be $1.12 \mathrm{mg} \cdot \mathrm{kg}^{-1}$ in Shenzheng, and $4.74 \mathrm{mg} \cdot \mathrm{kg}^{-1}$ in Qingdao, respectively.

$\mathrm{As}, \mathrm{Cd}, \mathrm{Pb}$ and $\mathrm{Hg}$ have been classified as potentially toxic elements due to their persistence, high bioavailability, and high toxicity. The lowest and highest As levels in clams were, respectively, $0.62 \mathrm{mg} \cdot \mathrm{kg}^{-1}$ in Shenzheng, and $9.66 \mathrm{mg} \cdot \mathrm{kg}^{-1}$ in Qingdao. The lowest and highest Cd levels were $0.64 \mathrm{mg} \cdot \mathrm{kg}^{-1}$ in Qinghuangdao and $1.11 \mathrm{mg} \cdot \mathrm{kg}^{-1}$ in Xiamen, respectively. The minimum and maximum $\mathrm{Pb}$ levels were found to be $0.44 \mathrm{mg} \cdot \mathrm{kg}^{-1}$ in Shenzheng, and $2.59 \mathrm{mg} \cdot \mathrm{kg}^{-1}$ in Fuzhou, respectively, while the lowest and highest $\mathrm{Hg}$ levels were, respectively, $0.05 \mathrm{mg} \cdot \mathrm{kg}^{-1}$ in Shenzheng, and $0.23 \mathrm{mg} \cdot \mathrm{kg}^{-1}$ in Qinghuangdao.

\subsection{Estimated Exposure and Hazards Quotients of Trace Elements}

The mean trace element concentrations were used to estimate the daily intake of trace elements through $R$. philippinarum consumption by the Chinese population. JFAO/WHO have set a PTWI of $\mathrm{Cu}$ as $3.5 \mathrm{mg} \cdot \mathrm{kg}^{-1} \mathrm{bw}$, a PTWI of Zn as $1.5 \mathrm{mg} \cdot \mathrm{kg}^{-1} \mathrm{bw}$, a PTWI of Mn as $0.98 \mathrm{mg} \cdot \mathrm{kg}^{-1} \mathrm{bw}$, a PTWI of Se as $0.035 \mathrm{mg} \cdot \mathrm{kg}^{-1} \mathrm{bw}$, a PTWI of Cd as $0.007 \mathrm{mg} \cdot \mathrm{kg}^{-1} \mathrm{bw}$, a PTWI of $\mathrm{Pb}$ as $0.025 \mathrm{mg} \cdot \mathrm{kg}^{-1} \mathrm{bw}$, a PTWI of $\mathrm{Hg}$ as $0.005 \mathrm{mg} \cdot \mathrm{kg}^{-1}$ bw and a PTWI of As as $0.015 \mathrm{mg} \cdot \mathrm{kg}^{-1} \mathrm{bw}$, respectively. Thus the values of ADI (mg.kg ${ }^{-1} \mathrm{bw} \cdot \mathrm{day}^{-1}$ ) calculated from PTWI were 0.5 for $\mathrm{Cu}, 0.21$ for $\mathrm{Zn}, 0.14$ for $\mathrm{Mn}$, 0.005 for $\mathrm{Se}, 0.001$ for $\mathrm{Cd}, 0.0036$ for $\mathrm{Pb}, 0.0007$ for $\mathrm{Hg}$ and 0.0021 for As, respectively. An average weight of $58.1 \mathrm{~kg}$ was assumed for a Chinese person based on statistics from 158,666 Chinese people from all provinces [27]. On average, the daily consumption rate of bivalves is $29 \mathrm{~g} / \mathrm{person} / \mathrm{day}$ in China [26]. The toxic effects of As depend on the chemical forms present, and it is only toxic if present in inorganic forms, such as arsenate and arsenite [28]. About 10\% of total As in marine organisms is present in inorganic forms [29]. Thus only inorganic As was considered in the hazard calculation. On this basis, the values of estimated daily intake (EDI) and hazard quotient (HQ) of trace elements are shown in Table 1. The calculated HQs of $\mathrm{Cu}, \mathrm{Zn}, \mathrm{Mn}, \mathrm{Se}, \mathrm{Ni}, \mathrm{Cd}, \mathrm{Cr}, \mathrm{Hg}$, and As in our study (except for $\mathrm{Pb}$, which did not have an $\mathrm{RfD}$ value) were all less than 1. 
Figure 2. Trace element concentrations ( $\mathrm{mg} \cdot \mathrm{kg}^{-1}$ dry weight) in Ruditapes philippinarum along the coast of China. Values with different marks represent significant difference at the significance level of 0.05. Data are expressed as mean \pm SD $(n=3)$. QHD: Qinghuangdao; DL: Dalian; QD: Qingdao; LYG: Lianyungang; NB: Ningbo; FZ: Fuzhou; XM: Xiamen; SZ: Shenzheng; BH: Beihai.
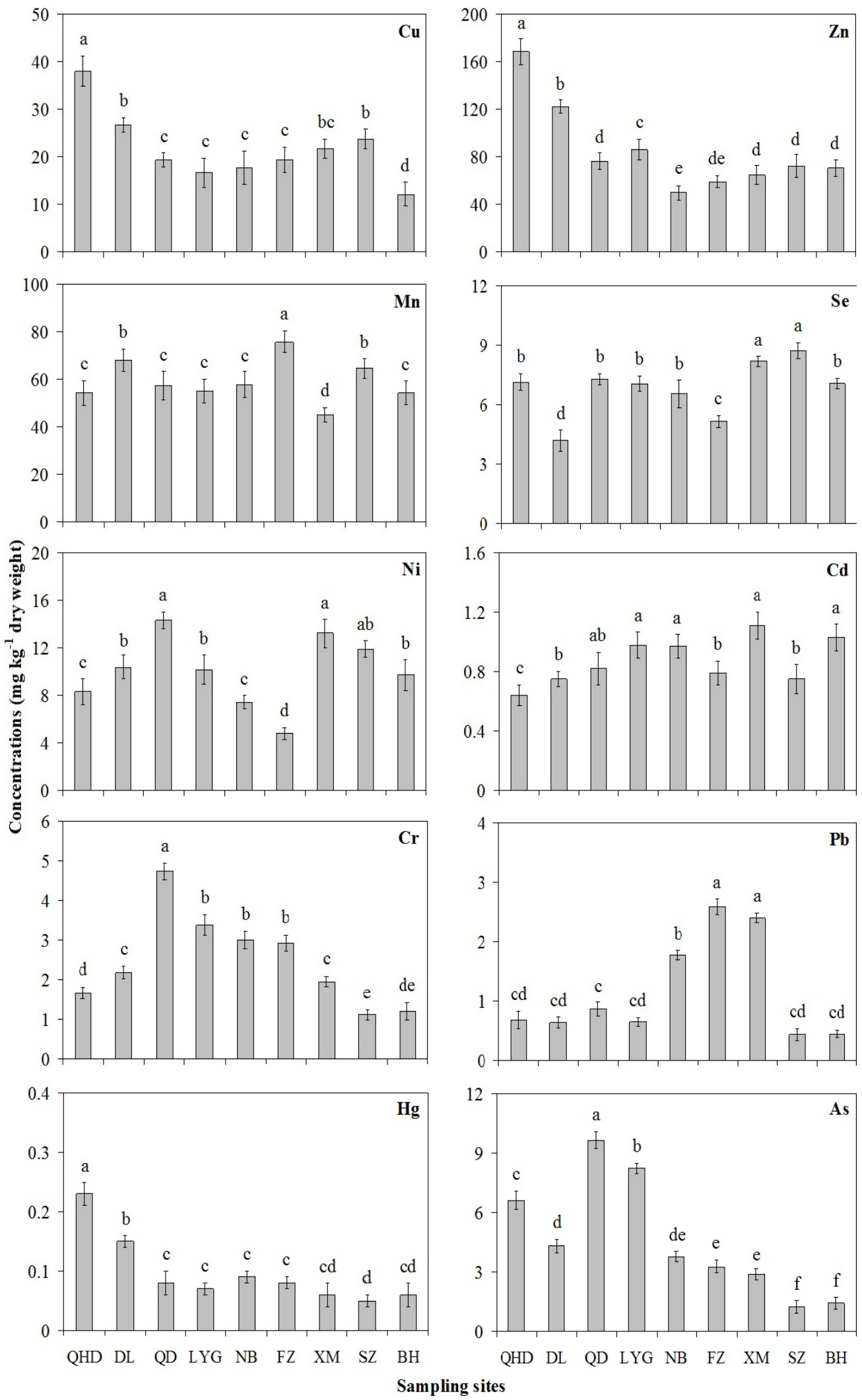
Table 1. Estimated daily intake (EDI) $\left(\mathrm{mg} \cdot \mathrm{kg}^{-1} \mathrm{bw} \cdot \mathrm{day}^{-1}\right)$ and hazard quotients (HQs) of trace elements through Ruditapes philippinarum consumption by people in China. Data reported based on wet weight are converted to dry weight basis for comparison using a wet weight/dry weight ratio of 7 . PTWI $\left(\mathrm{mg} \cdot \mathrm{kg}^{-1} \mathrm{bw}\right)$ : provisional tolerance weekly; ADI $\left(\mathrm{mg} \cdot \mathrm{kg}^{-1} \mathrm{bw} \cdot \mathrm{day}^{-1}\right)$ : Acceptable daily intake; Average concentrations of inorganic As were estimated as $10 \%$ of total As. n.a.: no available data.

\begin{tabular}{|c|c|c|c|c|c|c|c|c|c|c|c|}
\hline Location & & $\mathrm{Cu}$ & $\mathbf{Z n}$ & Mn & Se & $\mathrm{Ni}$ & Cd & $\mathrm{Cr}$ & $\mathbf{P b}$ & $\mathrm{Hg}$ & As \\
\hline Qinghuangdao & EDI & 0.002710 & 0.012001 & 0.003872 & 0.000509 & 0.000592 & 0.000046 & 0.000118 & 0.000048 & 0.000016 & 0.000047 \\
\hline Dalian & EDI & 0.001904 & 0.008721 & 0.004849 & 0.000299 & 0.000739 & 0.000053 & 0.000155 & 0.000046 & 0.000011 & 0.000031 \\
\hline \multirow{2}{*}{ Qingdao } & EDI & 0.001376 & 0.005441 & 0.004086 & 0.000519 & 0.001021 & 0.000058 & 0.000338 & 0.000061 & 0.000006 & 0.000069 \\
\hline & $\mathrm{HQ}$ & 0.0344 & 0.0181 & 0.0292 & 0.1038 & 0.0204 & 0.0580 & 0.1127 & n.a. & 0.0200 & 0.1725 \\
\hline Lianyungang & EDI & 0.001184 & 0.006132 & 0.003922 & 0.000503 & 0.000724 & 0.000070 & 0.000241 & 0.000046 & 0.000005 & 0.000059 \\
\hline Ningbo & $\mathrm{HQ}$ & 0.0316 & 0.0118 & 0.0294 & 0.0932 & 0.0106 & 0.0690 & 0.0713 & n.a. & 0.0200 & 0.0675 \\
\hline \multirow{2}{*}{ Fuzhou } & EDI & 0.001376 & 0.004207 & 0.005398 & 0.000367 & 0.000339 & 0.000056 & 0.000208 & 0.000185 & 0.000006 & 0.000023 \\
\hline & $\mathrm{HQ}$ & 0.0344 & 0.0140 & 0.0386 & 0.0734 & 0.0068 & 0.0560 & 0.0693 & n.a. & 0.0200 & 0.0575 \\
\hline \multirow{2}{*}{ Xiamen } & EDI & 0.001547 & 0.004613 & 0.003209 & 0.000583 & 0.000944 & 0.000079 & 0.000139 & 0.000171 & 0.000004 & 0.000021 \\
\hline & $\mathrm{HQ}$ & 0.0387 & 0.0154 & 0.0229 & 0.1166 & 0.0189 & 0.0790 & 0.0463 & n.a. & 0.0133 & 0.0525 \\
\hline Shenzheng & EDI & 0.001690 & 0.005155 & 0.004613 & 0.000621 & 0.000792 & 0.000053 & 0.000080 & 0.000031 & 0.000004 & 0.000004 \\
\hline ADI & & 0.5 & 0.21 & 0.14 & 0.005 & n.a. & 0.001 & n.a. & 0.0036 & 0.0007 & 0.0021 \\
\hline RfD & & 0.04 & 0.3 & 0.14 & 0.005 & 0.05 & 0.001 & 0.003 & n.a. & 0.0003 & 0.0004 \\
\hline
\end{tabular}




\section{Discussion and Conclusions}

\subsection{Geographical Variance}

Environmental factors such as metal concentration, speciation, food quality and quantity can be critical in influencing the metal accumulation in bivalves living in different environments [6]. In general, metals were heterogeneously distributed in bivalves and formed hot spot along the coastal areas. In our study, we discuss the geographical variance of trace elements in $R$. philippinarum, from the north to the south, by splitting the Chinese coastal areas into four subsections-Bohai Sea, Yellow Sea, East China Sea, and South China Sea (Figure 1).

It is well known that the Bohai Sea includes the most contaminated coastal areas in China. The fishery resource in the Bohai Sea has declined dramatically in the past twenty years because of overexploitation, eutrophication, and contamination [6]. Alarmingly high trace element levels were observed in $R$. philippinarum from the Bohai Sea (Table 2). Wang reported that the highest concentrations of $\mathrm{Cu}, \mathrm{Zn}, \mathrm{Mn}, \mathrm{Se}, \mathrm{Ni}, \mathrm{Cd}, \mathrm{Cr}, \mathrm{Pb}, \mathrm{Hg}$ and $\mathrm{As}$ in $R$. philippinarum were 25.7, 190.5, $94.8,23.10,14.25,3.71,19.1,2.00,0.27$ and $14.25 \mathrm{mg} \cdot \mathrm{kg}^{-1}$, respectively [15]. Bioaccumulation of Cd, $\mathrm{Co}, \mathrm{Cu}, \mathrm{Ni}, \mathrm{Pb}$, and $\mathrm{Zn}$ had obviously occurred in $R$. philippinarum from the Bohai Sea [30]. In our study, concentrations of $\mathrm{Cu}, \mathrm{Zn}, \mathrm{Mn}, \mathrm{Se}, \mathrm{Ni}, \mathrm{Cd}, \mathrm{Cr}, \mathrm{Pb}, \mathrm{Hg}$, and $\mathrm{As}$ in R. philippinarum from Qinghuangdao and Dalian ranged from 26.7-38.0, 122.3-168.3, 54.3-68.0, $4.19-7.14, \quad 8.30-10.37, \quad 0.64-0.75, \quad 1.66-2.18, \quad 0.64-0.68,0.15-0.23$ and $4.31-6.62 \mathrm{mg} \cdot \mathrm{kg}^{-1}$, respectively. $R$. philippinarum may be considerably contaminated by $\mathrm{Cu}, \mathrm{Zn}$, and $\mathrm{Hg}$ in the Bohai Sea. Zheng reported that the most contaminated areas along the Bohai Sea coastline is where the Huludao Zinc Plant is located, which is the largest zinc plant in Asia [31]. Extremely high $\mathrm{Cu}$ and $\mathrm{Zn}$ concentrations were found in vegetables due to zinc smelting activities [32]. The primary area of $\mathrm{Hg}$ contamination from the Bohai Sea is in the northern region, which has been polluted by industrial wastewater and sewage discharge [33]. Trace element levels observed in bivalves consistently reflect the elevated metal concentrations in this environment. Therefore, we recommend a sustained bivalve-based monitoring program in the Bohai Sea to test for locational differences as a function of anthropogenic activities, and to prevent potential human health risks.

Jiaozhou Bay, one of the most important clam-producing areas in China, has been recognized as the prototypical case of metal contamination in the Yellow Sea. It is a semi-closed bay situated in the northern part of Shandong Peninsula in China. In the recent years, the environment of this area has undergone serious deterioration and this poses a threat to the clam production in the area [34]. Many studies have reported the current metal contamination in $R$. philippinarum collected from Jiaozhou Bay (Table 2). Wang reported that the maximum concentrations of $\mathrm{Cu}, \mathrm{Zn}, \mathrm{Mn}, \mathrm{Ni}, \mathrm{Cd}, \mathrm{Cr}$ and $\mathrm{Pb}$ in $R$. philippinarum were 26.0, 110.3, 63.9, 52.75, 3.31, 35.47 and $14.77 \mathrm{mg} \cdot \mathrm{kg}^{-1}$, respectively [18]. The highest $\mathrm{Hg}$ and $\mathrm{As}$ in $R$. philippinarum levels reached 0.21 and $15.54 \mathrm{mg} \cdot \mathrm{kg}^{-1}$ [35]. Most of the highest trace element values occurred in bivalves collected from the northeast bay and the lowest values occurred in those collected from the western part [34,36]. In this study, concentrations of $\mathrm{Cu}$, $\mathrm{Zn}, \mathrm{Mn}, \mathrm{Se}, \mathrm{Ni}, \mathrm{Cd}, \mathrm{Cr}, \mathrm{Pb}, \mathrm{Hg}$ and $\mathrm{As}$ in $R$. philippinarum from Qingdao and Lianyungang ranged from 16.6-19.3, 76.3-86.0, 55.0-57.3, 7.05-7.28, 10.15-14.32, 0.82-0.98, 3.38-4.74, 0.65-0.86, 0.07-0.09 and 8.25-9.66 $\mathrm{mg} \cdot \mathrm{kg}^{-1}$, respectively. $R$. philippinarum from the Yellow Sea was 
significantly contaminated by $\mathrm{Cr}$ and As with the highest concentrations of 4.74 and $11.95 \mathrm{mg} \cdot \mathrm{kg}^{-1}$, respectively. Similarly, concentrations of these trace elements were concordant with those reported from Jiaozhou Bay (Table 2).

The East China Sea is one of the world's largest continental shelf systems, and receives the discharge from the Yangtze River that is the third largest river in the World [37]. Müller found that the metal levels in the suspended sediments from the Yangtze River were several times higher than those found in rivers in other countries, implying that significant quantities of metals are discharging into the East China Sea via this river [38]. Fung reported a mussel-based monitoring program, which was carried out along the East China Sea coast using Perna viridis and Mytilus edulis, and found that the concentrations of trace elements were, in general, higher or at least comparable to those reported in other regional studies [14]. On the contrary, Huang reported that Zhejiang coastal areas might be considered relatively unpolluted with trace elements and the concentrations of $\mathrm{Hg}, \mathrm{Cd}, \mathrm{Pb}, \mathrm{Zn}, \mathrm{Cu}$, and As in bivalves also below the seafood safety limits for human consumption [16]. Concentrations of $\mathrm{Cu}, \mathrm{Zn}, \mathrm{Mn}, \mathrm{Se}, \mathrm{Ni}, \mathrm{Cd}, \mathrm{Cr}, \mathrm{Pb}, \mathrm{Hg}$ and $\mathrm{As}$ in R. philippinarum from Ningbo, Fuzhou, and Xiamen ranged from 17.7-21.7, 49.5-64.7, 45.0-75.7, 5.15-8.18, 4.76-13.24, 0.79-1.11, 1.95-3.00, 1.78-2.59, 0.06-0.09 and 2.90-3.79 $\mathrm{mg} \cdot \mathrm{kg}^{-1}$, respectively. Lead contamination in $R$. philippinarum appeared significant in the East China Sea, with levels obtained several times higher than in clams collected from other sites (Table 2). Lin reported that the mean concentration of dissolved $\mathrm{Pb}(\sim 128 \mathrm{ng} / \mathrm{L})$ in the southern East China Sea is approximately several times higher than those in the Pacific Ocean, and the high dissolved $\mathrm{Pb}$ levels in the southern East China Sea waters correspond to much higher atmospheric supplies of $\mathrm{Pb}$ to the East China Sea [39].

It is generally considered that marine pollution in the southern China is relatively lower than in the northern part. High levels of trace metals in the South China Sea are mainly because of the enhanced industrial activities along the south coast of China, especially in the Pearl River Estuary, which is known as one of the most industrialized and urbanized regions in China and acts as a major sink for contaminants and nutrients in the surrounding ecosystem [6]. Fang reported that the concentrations of trace elements in molluscs collected from the Pearl River Estuary were significantly higher than those collected from other sites along the South China Sea coast [40,41]. Concentrations of $\mathrm{Cu}, \mathrm{Zn}, \mathrm{Mn}, \mathrm{Se}$, $\mathrm{Ni}, \mathrm{Cd}, \mathrm{Cr}, \mathrm{Pb}, \mathrm{Hg}$ and $\mathrm{As}$ in $\mathrm{R}$. philippinarum from Shenzheng and Beihai ranged from 12.1-23.7, $70.7-72.3, \quad 54.3-64.7,7.07-8.71,9.74-11.11,0.75-1.03,1.12-1.20,0.44-0.45,0.05-0.06$ and $0.62-0.72 \mathrm{mg} \cdot \mathrm{kg}^{-1}$, respectively. As shown in Table 2, trace element concentrations in R. philippinarum from the South China Sea were lower than from those collected from the Bohai, Yellow and East China Seas. 
Table 2. Comparison trace element concentrations $\left(\mathrm{mg} \cdot \mathrm{kg}^{-1}\right.$ dry weight) in Ruditapes philippinarum obtained in the present study with literature data from China and other regions all over the world. n.a.: no available data.

\begin{tabular}{|c|c|c|c|c|c|c|c|c|c|c|c|}
\hline Region & $\mathbf{C u}$ & $\mathbf{Z n}$ & Mn & Se & $\mathbf{N i}$ & Cd & $\mathrm{Cr}$ & $\mathbf{P b}$ & $\mathbf{H g}$ & As & Reference \\
\hline Bohai Sea, China & $20.0-38.0$ & $122.3-168.3$ & $47.5-68.0$ & $4.19-7.14$ & $8.30-12.26$ & $0.64-0.75$ & $1.66-2.29$ & $0.64-0.72$ & $0.15-0.23$ & $4.31-6.62$ & This study \\
\hline Yellow Sea, China & $14.0-19.3$ & $76.3-86.0$ & $51.0-57.3$ & $6.24-7.28$ & $10.15-14.32$ & $0.42-0.98$ & $3.38-4.74$ & $0.65-0.86$ & $0.07-0.09$ & $8.25-11.95$ & This study \\
\hline East China Sea, China & $17.7-21.7$ & $49.5-64.7$ & $45.0-75.7$ & $5.15-8.18$ & $4.76-13.24$ & $0.79-1.11$ & $1.95-3.00$ & $1.78-2.59$ & $0.06-0.09$ & $2.90-3.79$ & This study \\
\hline South China Sea, China & $12.1-23.7$ & $50.7-72.3$ & $42.0-64.7$ & $6.21-8.71$ & $8.40-9.74$ & $0.41-1.03$ & $0.94-1.25$ & $0.32-0.54$ & $0.03-0.06$ & $0.46-0.85$ & This study \\
\hline Bohai Sea, China & $7.5-25.7$ & $58.5-190.5$ & $14.1-94.8$ & $2.66-23.10$ & $9.90-14.25$ & $0.82-3.71$ & $0.94-19.1$ & $0.47-2.00$ & $0.08-0.27$ & $9.9-14.25$ & {$[15]$} \\
\hline Bohai Sea, China & $8.96-30.59$ & $70.0-140.4$ & n.a. & n.a. & $5.04-20.79$ & $0.98-4.41$ & n.a. & $0.91-2.38$ & n.a. & n.a. & {$[30]$} \\
\hline Jiaozhou Bay, China & $5.1-26.0$ & $52.1-110.3$ & $10.3-63.9$ & n.a. & $5.26-52.75$ & $0.65-3.31$ & $9.64-35.47$ & $0.89-14.77$ & n.a. & n.a. & {$[18]$} \\
\hline Jiaozhou Bay, China & $7.7-9.1$ & $62.2-87.1$ & n.a. & n.a. & n.a. & $0.39-0.68$ & $0.96-4.04$ & $0.53-1.42$ & $0.04-0.07$ & $8.32-14.33$ & [34] \\
\hline Jiaozhou Bay, China & $8.8-21.5$ & n.a. & n.a. & n.a. & n.a. & $0.07-1.05$ & $9.03-10.92$ & $2.10-3.64$ & $0.02-0.21$ & $9.80-15.54$ & {$[35]$} \\
\hline Jiaozhou Bay, China & $6.4-19.8$ & $35.5-85.5$ & $27.45-67.6$ & n.a. & n.a. & $0.51-0.67$ & n.a. & $0.31-1.01$ & n.a. & n.a. & {$[36]$} \\
\hline East China Sea, China & $9.2-14.4$ & $26.0-73.5$ & n.a. & n.a. & n.a. & $0.48-0.85$ & n.a. & $0.23-0.42$ & $0.06-0.15$ & $2.47-3.45$ & {$[16]$} \\
\hline South China Sea, China & $6.0-10.0$ & $71.0-116.0$ & n.a. & n.a. & n.a. & $0.60-5.00$ & $0.20-14.50$ & $0.80-2.70$ & n.a. & n.a. & [6] \\
\hline Pearl River Delta, China & $4.0-10.1$ & $39.4-212.9$ & n.a. & n.a. & $5.04-5.88$ & $0.42-1.19$ & $3.85-4.13$ & $1.47-1.75$ & n.a. & n.a. & {$[40]$} \\
\hline Pearl River Delta, China & $5.2-13.9$ & $54.9-74.6$ & n.a. & n.a. & $9.78-23.72$ & $0.30-7.60$ & $3.13-12.25$ & $1.50-14.99$ & n.a. & n.a. & [41] \\
\hline Southern Atlantic, Spanish & $5.1-26.0$ & $52.1-110.3$ & $10.3-63.9$ & n.a. & $5.26-52.75$ & $0.47-2.71$ & $9.6-35.5$ & $0.41-1.94$ & $0.13-2.72$ & $12.60-32.20$ & [9] \\
\hline Gironde Estuary, France & $9.4 \pm 1.0$ & $97.2 \pm 8.0$ & n.a. & n.a. & n.a. & $0.52 \pm 0.11$ & n.a. & n.a. & n.a. & n.a. & [11] \\
\hline Kyeonggi Bay, Korea & $5.5-14.3$ & $64.7-162.0$ & $20.5-177.0$ & n.a. & $2.74-33.50$ & $0.53-2.20$ & $0.61-2.38$ & $0.34-1.72$ & n.a. & n.a. & {$[20]$} \\
\hline Shihwa Lake, Korea & $6.6-23.2$ & $70.0-144.0$ & n.a. & n.a. & $3.20-13.4$ & $0.56-1.11$ & $0.42-1.40$ & $0.50-1.82$ & n.a. & $12.4-18.3$ & {$[21]$} \\
\hline Venice lagoon, Italy & $8.2-29.0$ & $60.0-122.0$ & $8.0-29.1$ & n.a. & $0.15-8.37$ & $0.26-2.19$ & $1.89-5.70$ & $0.49-2.54$ & $0.25-2.30$ & $18.90-64.00$ & {$[22]$} \\
\hline
\end{tabular}




\subsection{Public Health Risk Assessment}

The estimated daily intake (EDI) of $R$. philippinarum lead to estimates of trace element consumption in the range of 1.3-68.3 times lower than the RfD guidelines for all trace elements studied, thus strongly indicating that people would not experience significant health risks from the intake of trace elements through clams $R$. philippinarum consumption along the coast of China. According to the FAO [26], the average seafood and fish consumption of Chinese people is $42 \mathrm{~g} /$ person/day, including freshwater fish $29 \mathrm{~g} /$ person/day, marine fish $3 \mathrm{~g} / \mathrm{person} /$ day and shellfish $29 \mathrm{~g} /$ person/day. However, people living along the coast are expected to consume much more seafood than people living inland. In Hong Kong, for example, the estimated daily consumption of marine fish is $25 \mathrm{~g}$ /day (or eight times higher than the average Chinese consumption) [23]. In our study, daily clam consumption was assumed as the daily shellfish consumption of Chinese people. Even with such high clam consumption, the EDI was also lower than the established ADI. Our calculations suggested that the HQs of all trace elements examined in this study, except for $\mathrm{Pb}$, which did not have the RfD value, were all less than 1, suggesting that the consumption of clams did not present any risk to humans. Nevertheless, attention should be given to As, as the relatively high HQ values of As in the present study indicated that the contamination of As in clams may present a potential human health risk.

\section{Acknowledgments}

We thank the anonymous reviewers for their helpful comments on this work. This project was supported by the earmarked fund for Modern Agro-industry Technology Research System (CARS-48) and the State Oceanic Administration of China (200905020).

\section{Conflict of Interest}

The authors declare no conflict of interest.

\section{References}

1. Maanan, M. Heavy metal concentrations in marine mollusks from the Moroccan coastal region. Environ. Pollut. 2008, 153, 176-183.

2. Rainbow, P.S. Trace metal concentrations in aquatic invertebrates, why and so what? Environ. Pollut. 2002, 120, 497-507.

3. Rainbow, P.S.; Wolowicz, M.; Fialkowski, W.; Smith, B.D.; Sokolowski, A. Biomonitoring of trace metals in the Gulf of Gdansk, using mussels (Mytilus trossulus) and barnacles (Balanus improvisus). Water. Res. 2000, 34, 1823-1829.

4. Szefer, P.; Frelek, K.; Szefer, K.; Lee, C.B.; Kim, B.S.; Warzocha, J.; Zdrojewska, I.; Ciesielski, T. Distribution and relationships of trace metals in soft tissue, byssus and shells of Mytilus edulis trossulus from the southern Baltic. Environ. Pollut. 2002, 120, 423-444.

5. Saha, M.; Sarkar, S.K.; Bhattacharya, B. Interspecific variation in heavy metal body concentrations in biota of Sunderban mangrove wetland, northeast India. Environ. Int. 2006, 32, 203-207. 
6. Pan, K.; Wang, W.X. Trace metal contamination in estuarine and coastal environments in China. Sci. Total. Environ. 2011, 421-422, 3-16.

7. Zhao, L.; Yang, F.; Yan, X.; Huo, Z.; Zhang, G. Heavy metal concentrations in surface sediments and Manila clams (Ruditapes philippinarum) from the Dalian coast, China after the Dalian Port oil spill. Biol. Trace. Elem. Res. 2012, 149, 241-247.

8. Szefer, P.; Kim, B.S.; Kim, C.K.; Kim, E.H.; Lee, C.B. Distribution and coassociations of trace elements in soft tissue and byssus of Mytilus galloprovincialis relative to the surrounding seawater and suspended matter of the southern part of the Korean Peninsula. Environ. Pollut. 2004, 129, 209-228.

9. Usero, J.; Morillo, J.; Gracia, I. Heavy metal concentrations in molluscs from the Atlantic coast of southern Spain. Chemosphere 2005, 59, 1175-1181.

10. Mertz, W. The essential trace elements. Science 1981, 213, 1332-1338.

11. Baudrimont, M.; Schäfer, J.; Marie, V.; Maury-Brachet, R.; Bossy, C.; Boudou, A.; Blanc, G. Geochemical survey and metal bioaccumulation of three bivalve species (Crassostrea gigas, Cerastoderma edule and Ruditapes philippinarum) in the Nord Médoc salt marshes (Gironde estuary, France). Sci. Total. Environ. 2005, 337, 265-280.

12. Sapkota, A.; Sapkota, A.R.; Kucharski, M.; Burke, J.; Mckenzie, S.; Walker, P.; Lawrence, R. Aquaculture practices and potential human health risks, current knowledge and future priorities. Environ. Int. 2008, 34, 1215-1226.

13. Mostafa, A.R.; Al-Alimi, A.K.A.; Barakat, A.O. Metals in surface sediments and marine bivalves of the Hadhramout coastal area, Gulf of Aden, Yemen. Mar. Pollut. Bull. 2009, 58, 308-311.

14. Fung, C.N.; Lam, J.C.W.; Zheng, G.J.; Connell, D.W.; Monirith, I.; Tanabe, S. Mussel-based monitoring of trace metal and organic contaminants along the east coast of China using Perna viridis and Mytilus edulis. Environ. Pollut. 2004, 127, 203-216.

15. Wang, Y.W.; Liang, L.N.; Shi, J.B.; Jiang, G.B. Study on the contamination of heavy metals and their correlations in mollusks collected from coastal sites along the Chinese Bohai Sea. Environ. Int. 2005, 31, 1103-1113.

16. Huang, H.; Wu, J.Y.; Wu, J.H. Heavy metal monitoring using bivalved shellfish from Zhejiang Coastal Waters, East China Sea. Environ. Monit. Assess. 2007, 129, 315-320.

17. Zhang, G.; Yan, X.; Yang, F. A new three-phase culture method for Manila clam, Ruditapes philippinarum, farming in northern China. Aquaculture 2006, 258, 452-461.

18. Wang, X.Y.; Zhou, Y.; Yang, H.S.; Wang, Q.; Liu, S. Investigation of heavy metals in sediments and Manila clams Ruditapes philippinarum from Jiaozhou Bay, China. Environ. Monit. Assess. 2010, 170, 631-643.

19. Usero, J.; Gonzalez-Regalado, E.; Gracia, I. Trace metals in the bivalve molluscs Ruditapes decussatus and Ruditapes philippinarum from the Atlantic Coast of Southern Spain. Environ. Int. 1997, 23, 291-298.

20. Ji, J.Y.; Choi, H.J.; Ahn, I.Y. Evaluation of Manila clam Ruditapes philippinarum as a sentinel species for metal pollution monitoring in estuarine tidal flats of Korea: Effects of size, sex, and spawning on baseline accumulation. Mar. Pollut. Bull. 2006, 52, 447-453. 
21. Ra, K.; Kim, K.T.; Bang, J.H.; Lee, J.M.; Kim, E.S.; Cho, S.R. A preliminary study of environmental impact assessment of tidal power plant in Shihwa Lake, Korea: Heavy metal accumulation in the transplanted Manila clam (Ruditapes philippinarum). J. Coast. Res. 2011, 64, 932-936.

22. Sfriso, A.; Argese, E.; Bettiol, C.; Facca, C. Tapes philippinarum seed exposure to metals in polluted areas of the Venice lagoon. Estuar. Coast. Shelf. Sci. 2008, 79, 581-590.

23. Onsanit, S.; Ke, C.H.; Wang, X.H.; Wang, K.J.; Wang, W.X. Trace elements in two marine fish cultured in fish cages in Fujian province, China. Environ. Pollut. 2010, 158, 1334-1342.

24. Joint Food and Agriculture Organization/World Health Organization Expert Committee on Food Additives. Summary and Conclusions of the 61st Meeting of the Joint FAO/WHO Expert Committee on Food Additives. In Proceedings of JECFA/61/Sc, Rome, Italy, 10-19 June 2003; pp. 1-22.

25. Risk-based Concentration Table. United States Environmental Protection Agency: Philadelphia, PA, USA, 2011.

26. FAO. Food Security Statistics, Food Consumption; Statistics Division, Food and Agricultural Organization of the United Nations: Rome, Italy, 2008.

27. Gu, Y.; He, J.; Duan, X.F.; Reynolds, K.; Wu, X.; Chen, J.; Huang, G.; Chen, C.S.; Whelton, P.K. Body weight and mortality among men and women in China. J. Am. Med. Assoc. 2006, 295, 776-783.

28. Ng, J.C. Environmental contamination of arsenic and its toxicological impact on humans. Environ. Chem. 2005, 2, 146-160.

29. United States Food and Drug Administration. Guidance Documents for Trace Elements in Seafood; Center for Food Safety and Applied Nutrition: Washington, DC, USA, 1993.

30. Liang, L.N.; He, B.; Jiang, G.B.; Chen, D.Y.; Yao, Z.W. Evaluation of mollusks as biomonitors to investigate heavy metal contaminations along the Chinese Bohai Sea. Sci. Total. Environ. 2005, $324,105-113$.

31. Zheng, N.; Liu, J.; Wang, Q.; Liang, Z. Health risk assessment of heavy metal exposure to street dust in the zinc smelting district, Northeast of China. Sci. Total. Environ. 2010, 408, 726-733.

32. Zheng, N.; Wang, Q.; Zheng, D. Health risk of $\mathrm{Hg}, \mathrm{Pb}, \mathrm{Cd}, \mathrm{Zn}$, and $\mathrm{Cu}$ to the inhabitants around Huludao Zinc Plant in China via consumption of vegetables. Sci. Total. Environ. 2007, 383, 81-89.

33. Wang, Y.W.; Liang, L.N.; Shi, J.B.; Jiang, G.B. Chemometrics methods for the investigation of methylmercury and total mercury contamination in mollusks samples collected from coastal sites along the Chinese Bohai Sea. Environ. Pollut. 2005, 135, 457-467.

34. Ma, H.; Song, Q.; Wang, X. Accumulation of petroleum hydrocarbons and heavy metals in clams (Ruditapes philippinarum) in Jiaozhou Bay, China. Chin. J. Oceanol. Limnol. 2009, 27, 887-897.

35. Zhu, X.; Xu, W.; Wang, X.; Huang, X.; Deng, L.; Kang, X. Research on heavy metals in Ruditapes philippinarum and soda industry wastes. Chin. J. Oceanol. Limnol. 2005, 23, 39-42.

36. Li, Y.; Yu, Z.; Song, X.; Mu, Q. Trace metal concentrations in suspended particles, sediments and clams (Ruditapes philillinarum) from Jiaozhou Bay of China. Environ. Monit. Assess. 2006, 121, 491-501.

37. Asante, K.A.; Agusa, T.; Mochizuki, H.; Ramu, K.; Inoue, S.; Kubodera, T.; Takahashi, S.; Subramanian, A.; Tanabe, S. Trace elements and stable isotopes $\left(\delta^{13} \mathrm{C}\right.$ and $\left.\delta^{15} \mathrm{~N}\right)$ in shallow and deep-water organisms from the East China Sea. Environ. Pollut. 2008, 156, 862-873. 
38. Müller, B.; Berg, M.; Yao, Z.P.; Zhang, X.F.; Wang, D.; Pfluger, A. How polluted is the Yangtze river? Water quality downstream from the Three Gorges Dam. Sci. Total. Environ. 2008, 402, 232-247.

39. Lin, F.J.; Hsu, S.C.; Jeng, W.L. Lead in the southern East China Sea. Mar. Environ. Res. 2000, 49, 329-342.

40. Fang, Z.Q.; Cheung, R.Y.H.; Wong, M.H. Heavy metal concentrations in edible bivalves and gastropods available in major markets of the Pearl River Delta. J. Environ. Sci. China 2001, 13, 210-217.

41. Fang, Z.Q.; Cheung, R.Y.H.; Wong, M.H. Heavy metals in oysters, mussels and clams collected from coastal sites along the Pearl River Delta, South China. J. Environ. Sci. China 2003, 15, 9-24.

(C) 2013 by the authors; licensee MDPI, Basel, Switzerland. This article is an open access article distributed under the terms and conditions of the Creative Commons Attribution license (http://creativecommons.org/licenses/by/3.0/). 